\title{
Announcements
}

\section{Editorial: U.S. Earth System History Program in Transition}

A significant portion of paleoclimate science conducted by the United States over the past 14 years has been carried out through proposals to the Earth System History (ESH) Program of the U.S. National Science Foundation (NSF). This cross-disciplinary program has been jointly supported under the Directorate for Geosciences with contributions from its divisions, including Earth Sciences, Ocean Sciences and Atmospheric Sciences. Initially developed under the U.S. Global Change Research Program involving a number of federal agencies, NSF acutely acknowledged the need for a program to promote pioneering research on the temporal and spatial scales of natural climate variability, climate proxies, and modeling in order to better understand the forcing mechanisms, systemic sensitivities, and feedbacks responsible for past climate change on regional and global scales. Partnerships for shared support of selected proposals were also fostered in the earlier years with the NSF Office of Polar Programs and the National Oceanic and Atmospheric Administration's (NOAA) former Paleoclimate element in the Office of Global programs (now known as the Climate Change Data and Detection element in the Climate Program Office).

Since its inception, the ESH program has been guided by an adhoc advisory group composed of scientists on rotation from a range of disciplines who periodically sought community input to guide program managers in developing targeted areas of emphasis for annual solicitations as the science evolved. The program has supported a vast range of projects world-wide, primarily but not exclusively, aimed at high-resolution climate records using a variety of sedimentary, geochemical, and biogeochemical paleo-proxies from diverse environments to develop both qualitative and quantitative estimates of past change. The program has particularly encouraged over time the integration of empirical and observational data with a variety of model simulations of regional and global climate change. Recent initiatives of emphasis within the ESH program have focused on topics including Holocene change, abrupt change on a variety of timescales, and regional vs. global scale change.

Because the solicitation for the ESH program expires September 30, 2006, NSF and the science community are now poised to determine how this successful program might evolve in the coming years to address ongoing and future scientific needs (see www.nsf.gov/pubs/2006/nsf06029/nsf06029.jsp). Plans are now being formulated for an official review, during which time the Directorate for Geosciences will continue to seek community input during the decision making process. An initial workshop held in November 2005 focused on a few relevant cross-cutting science questions and the workshop recommendations are available at www. mesh.usc.edu/workshop.htm for community comment.

The short articles presented in this issue were volunteered at large from ESH-funded researchers and represent only a small cross-section of the range of science address by the ESH initiative. To learn more about past ESH initiatives, go to the ESH website at www.nsf.gov/funding/pgm_summ.jsp?pims_id=5750\&org=ATM.

JULIE BRIGHAM-GRETTE

PAGES SSC Chair

juliebg@geo.umass.edu

\section{Tales from the field}

Do you have an interesting and humorous story from your paleoenvironmental fieldwork? Send us your tale (max. 500 words) so that we can publish it in PAGES News!

\section{PAGES newsletters: Would you prefer a digital copy?}

\section{Digital Newsletter}

PAGES News is also available electronically. If you subscribe to the digital newsletter, we will send you an email each time a new issue is published, with the link to the website where you can download a low- or highresolution Acrobat pdf. If you would like to sign up for the digital version, please send an email to Leah Christen (christen@pages.unibe.ch).

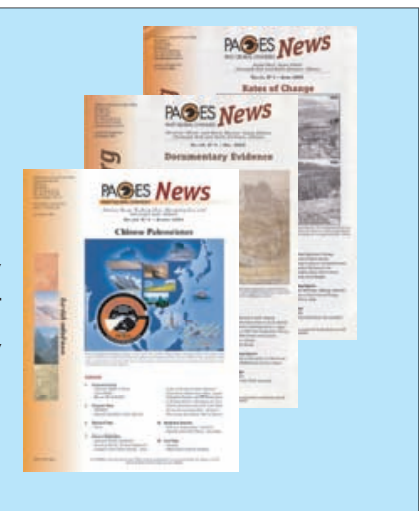

